\title{
Discussion of "Examining the Risk of Electric Shock Drowning (ESD) As a Function of Water Conductivity"
}

This paper was downloaded from TechRxiv (https://www.techrxiv.org).

\section{LICENSE}

CC BY 4.0

SUBMISSION DATE / POSTED DATE

27-09-2020 / 26-10-2020

CITATION

Linja-aho, Vesa (2020): Discussion of "Examining the Risk of Electric Shock Drowning (ESD) As a Function of Water Conductivity". TechRxiv. Preprint. https://doi.org/10.36227/techrxiv.13012355.v2

$\mathrm{DOI}$

10.36227/techrxiv.13012355.v2 


\title{
Discussion of "Examining the Risk of Electric Shock Drowning (ESD) As a Function of Water Conductivity"
}

\author{
Vesa Linja-aho, Member, IEEE
}

\begin{abstract}
A FTER reading an interesting article [1] on electric shock drowning (ESD), my first reaction as an experienced Finnish electrical safety expert was bafflement: I had never read or heard about an accident where current leaking from a boat or marina has killed a swimmer in natural water, although I live in a country marketed for tourists as a Land of Thousand Lakes [2]. Finland is an industrialized country with 5.5 millions of population and is one of the most boat-dense countries in the world, with 1.2 million boats, of which 200,000 are registered [3]. In Finnish Electric Safety Authority fatal accident database [4], which covers all fatal electrical accidents from year 1980, no single incident of this type can be found. The accidents involving presence of water $(n=8)$ have all happened when using an electric power tool or pump while standing in water or when a plugged-in hairdryer has dropped in bathtub while bathing.
\end{abstract}

In Sweden (population 10.2 million), deaths involving electricity do not contain any accident involving a natural water swimmer during the years 2011-2019, and the previous yearly reports of Swedish Electric Safety Authority [5] do not contain any mention of this kind of danger. According to Canadian Yachting magazine [6], there has neither been any fatalities in Canada. Canada, not speaking of Sweden or Finland, are small countries by population if compared to the United States, but the population difference does not explain the total missing of these kinds of accidents, as there have been at least 30 accidents [1] between 1999 and 2010 in the United States.

After an extensive search in Web of Science, IEEE Xplore, Scopus, Google Scholar as well as regular Google search engine to find newspaper articles, all instances and media coverage on accidents involving an electric current killing a swimmer in sea or a lake seem to have happened in the United States. Fatal electrocutions of swimmers outside the U.S. have happened in swimming pools and waterparks, of which the 2017 incident in Turkey [7], killing three children and two of their would-be rescuers, is the most recent and well-known. Therefore, either the electric shock drowning in natural water is prevalent only in the United States or the incidents are not recognized elsewhere. The latter is not likely in industrialized countries with strict safety legislation: if a person able to swim suddenly drowns with no apparent reason, the cause of death will be investigated in autopsy. Additionally, the tingling caused by the current would be noticed by other swimmers and the reason investigated - and as a strange incident, reach the main headlines in the media, as has happened in the United States.

This raises the next question: if natural water electric shock drowning is a problem only in United States, what are the reasons behind this? One reason might be differences in the residual current protection. In European Union, a $30 \mathrm{~mA} \mathrm{RDC}$ has been mandatory in all new marina socket-outlet installations since the 1990's (the exact year depends on the national legislation, in Finland it was 1997). The requirement was introduced in IEC standard 60364-7-709:1994, and it concerned groups of socket outlets. In the next edition of the standard (2007), the requirement was improved so that every socket-outlet shall be individually protected by an RCD having a rated residual operating current not exceeding $30 \mathrm{~mA}$.

In the United States, the RDC protection for marinas was introduced in National Electrical Code (NEC) 2017, requiring $30 \mathrm{~mA}$ protection total for the system. According to [8], this lead to situation where only a few vessels - each apparently leaking a small amount of current - caused the protection to trip. This is now taken into account in the 2020 edition of the code, which requires $30 \mathrm{~mA}$ RCD for each socket-outlet individually and $100 \mathrm{~mA} \mathrm{RCD}$ for the system.

The NFPA article also raises a possible difference in safety culture between countries: according to [8], the tripping of the RCD prompted marina owners to remove the ground-fault protection devices. In Finland, bypassing or removing protective devices from electrical installations is both socially unacceptable and a criminal offence and probable end result for such accidental tripping would be fixing the leaky installations in the boats.

Other lesson-to-learn is the importance of the international co- 
operation in the electric safety field, to avoid repeating mistakes already done in other countries. The change in IEC standard from the $30 \mathrm{~mA} \mathrm{RCD}$ for the group of socket-outlets (1994) to individual RCD:s for each outlet (2007) has probably had the same motivation as in the NEC change from 2017 to 2020: when leakage currents sum up, the RCD will trip and cause all the boats lose power. As the standards traditionally do not include commentaries nor motivations for changes, it is easy to repeat the same mistakes. The good news is that this is changing, IEC has been started to publish commented versions [9] of international safety standards.

\section{REFERENCES}

[1] M. Morse, J. Kotsch, B. Prussak and J. G. Kohl, "Examining the Risk of Electric Shock Drowning (ESD) As a Function of Water Conductivity," in IEEE Transactions on Industry Applications, vol. 56, no. 4, pp. 43244328, July-Aug. 2020, doi: 10.1109/TIA.2020.2982854.

[2] L. Li, "A Land of a Thousand Lakes," The New York Times, Apr. 16, 1989.

[3] Traficom, "Finland, The Land of Over a Million boats [in Finnish]," Feb. 16, 2017.

https://arkisto.trafi.fi/uutisarkisto/4780/suomi_yli_miljoonan_veneen_m aa (accessed Sep. 25, 2020).

[4] Tukes, "Fatal electrocutions [in Finnish]," Turvallisuus- ja kemikaalivirasto (Tukes), 2020.

https://tukes.fi/onnettomuudet/sahkokuolemat (accessed Sep. 25, 2020).

[5] "Electrical Accident Reports [in Swedish]," Elsäkerhetsverket. https://www.elsakerhetsverket.se/om-oss/vi-arbetar-med/utredningaroch-analyser/elolyckor/Elolycksfallsrapporter/ (accessed Sep. 27, 2020).

[6] Ethan, "Never Swim in a Marina - Lake Fatalities Highlight Need for Electrical Safety," Canadian Yachting.

https://www.canadianyachting.ca/news-and-events/current/2350-neverswim-in-a-marina-lake-fatalities-highlight-need-for-electrical-safety (accessed Sep. 27, 2020).

[7] The Associated Press, "5 people die after being electrocuted at water park in Turkey |CBC News," CBC, Jun. 23, 2017. https://www.cbc.ca/news/world/turkey-water-park-electrocution1.4175233 (accessed Sep. 27, 2020).

[8] Vigstol, Derek, "Electric vehicles and marinas in the 2020 NEC." http://www.nfpa.org/News-and-Research/Publications-andmedia/NFPA-Journal/2020/July-August-2020/In-Compliance/NFPA-70 (accessed Sep. 27, 2020).

[9] N. Mouyal and 9 September 2020, "IEC publishes revised standard on the safety of household appliances," IEC e-tech, Sep. 09, 2020. https://etech.iec.ch/issue/iec-publishes-revised-standard-on-the-safetyof-household-appliances (accessed Sep. 27, 2020). 